\title{
ANALISIS BENTUKLAHAN SEBAGAI LANDASAN TERWUJUDNYA SUSTAINABLE COASTAL AREA DI INDONESIA
}

\author{
Afid Nurkholis, Galih Dwi Jayanto, Nuringtyas Yogi Jurnawan. ${ }^{1}$ \\ ${ }^{1}$ Departemen Geografi Lingkungan, Fakultas Geografi, \\ Universitas Gadjah Mada, Yogyakarta
}

\begin{abstract}
ABSTRAK
Indonesia merupakan negara maritim dengan ribuan gugusan kepulauan yang terbentang dari Pulau Sabang di ujung barat hingga Pulau Merauke di ujung timur. Wilayah pesisir menjadi kawasan strategis untuk menunjang pembangunan nasional ditinjau dari segi lokasinya maupun keunikan karakteristik di setiap pesisirnya. Ibu kota negara Jakarta dan beberapa kota metropolitan Indonesia juga terletak strategis di wilayah pesisir seperti Surabaya, Semarang, Bali, dan Makassar. Namun, limpahan potensi materiil dan non materiil tersebut menghadapi tantangan besar akibat letak Indonesia yang berada di jalur subduksi. Bencana seperti gempabumi, tsunami, dan banjir rob dapat datang sewaktu-waktu. Penelitian ini bertujuan mengetahui karakteristik bentuklahan pesisir di Indonesia, potensi sumberdaya dan ancaman bencana di setiap tipologi, dan yang terakhir mewujudkan manajemen kepesisiran berbasis sustainable coastal area berdasarkan tiga tujuan di atas. Data karakteristik pesisir diperoleh dengan survey lapangan, studi literature, dan interpretasi citra satelit GeoEye. Karakteristik bentuklahan mencakup morfologi, material, dan proses yang khas di setiap unitnya sehingga potensi sumberdaya dan ancaman bencananya pun juga tidak dapat disamakan tiap unitnya. Penelitian dilakukan di karakteristik pesisir yang dominan di Indonesia yaitu marine deposition coast, subaerial deposition coast, dan karst coast. Perbedaan karakteristik tersebut menjadikan perwujudan pengelolaan pesisir secara sustainable coastal dapat menjadi sebuah solusi, selain mengetahui karakteristik, potensi sumberdaya, dan ancaman bencananya hal yang dapat dilakukan adalah dengan melakukan zonasi berdasarkan karakteristik bentuklahan dan peruntukan yang tepat untuk mewujudkan kawasan pesisir yang lestari.
\end{abstract}

Kata Kunci: ancaman bencana, bentuklahan, karakteristik pesisir, sustainable coastal, potensi 


\title{
LANDFORM ANALYSIS AS THE PLATFORM FACTOR OF SUSTAINABLE COASTAL AREA IN INDONESIA
}

\author{
Afid Nurkholis, Galih Dwi Jayanto, Nuringtyas Yogi Jurnawan. ${ }^{1}$ \\ ${ }^{1}$ Departemen Geografi Lingkungan, Fakultas Geografi, \\ Universitas Gadjah Mada, Yogyakarta
}

\begin{abstract}
Indonesia is a maritime country with thousands of islands that stretches from Sabang to Merauke. Coastal area is a strategic sector to support national development in terms of its location and its unique characteristics. Large sums of metropolitan cities, such as Jakarta, Surabaya, Semarang, Bali and Makassar are located in the coastal area. However, those locations are facing multiple risks as it lies on the path of subduction that susceptible of disaster such as earthquake, tsunami, and coastal flooding. This study aims to analyze the characteristics of coastal landform in Indonesia, potential resources and typological hazards. The last but not the least is to implement coastal area management based on sustainable coastal area analysis. Coastal characteristic data in this research obtained from field survey, literature study, and Geo-Eye image interpretation. Landform characteristics including morphological, material, and process are varied in each unit, thus the potential resource and the hazard are different as well. The study was conducted in a dominant coastal area in Indonesia, namely marine depositional coast, subaerial depositional coast, and karst coast. The difference of these characteristics functions as a solution to the embodiment of sustainable coastal management in addition to understand the characteristics, potential resources, and the hazard. Zoning based on landform characteristic can be an appropriate approach to solve the problem.
\end{abstract}

Keywords: coastal characteristic, hazard, landform, sustainable coastal, potential resource 


\section{BAB I: PENDAHULUAN}

\section{A. Latar Belakang}

Indonesia merupakan negara kepualauan yang terdiri dari 17.508 pulau dan memiliki panjang garis pantai lebih dari $81.000 \mathrm{~km}$ serta memiliki luas laut sekitar 3,1 juta km2 sehingga wilayah pesisir dan lautan Indonesia dikenal sebagai negara dengan kekayaan dan keanekaragaman hayati terbesar di dunia (Dahuri dkk, 1996). Dengan kondisi yang demikian, wilayah pesisir Indonesia menjadi daya tarik yang besar bagi masyarakat untuk hidup dan menghidupi. Hal ini ditunjukkan dengan sebagaian besar penduduk Indonesia yakni sekitar $60 \%$ dari jumlah penduduk tinggal di wilayah pesisir (www.terangi.or.id).

Wilayah pesisir merupakan lingkungan yang strategis untuk berbagai kegiatan terutama pembangunan. Kegiatan pembangunan di wilayah pesisir terjadi begitu pesat dan massif (Dahuri dkk, 1996). Ini dibuktikan dengan perkembangan kota-kota besar di Indonesia yang sebagian besar berada di wilayah pesisir seperti Jakarta, Semarang, Surabaya dan Makassar sebagai pusat pembangunan. Kegiatan pembangunan tersebut sudah pasti memanfaatkan ruang di wilayah pesisir untuk berbagai kegiatan seperti pembangunan pusat pemerintahan, pusat industri, pertanian dan perikanan.

Bentuklahan merupakan bagian dari ruang di permukaan bumi yang memiliki kekhasan dalam hal morfologi, proses geomorfologi, material permukaan maupun batuan dasar (Verstappen, 1983). Setiap bentuklahan memiliki potensi pemanfaatan dan ancaman bencana yang khas. Pemanfaatan wilayah pesisir yang tidak memperhatikan keseimbangan lingkungan dapat menimbulkan degradasi lingkungan maupun ancaman bencana yang datang setiap saat (Panizza, 1996). Contoh degradasi lingkungan yang terjadi di wilayah pesisir seperti erosi pantai, sedimentasi, land subsidence, intrusi air laut, pencemaran dan lain sebagainya. Selain itu, sumberdaya pesisir yang melimpah tidak bisa dimanfaatkan dengan optimal jika tidak dilakukan perencanaan yang berbasis lingkungan. 
Oleh karena itu, mengingat tingkat urgensitas wilayah pesisir sangat tinggi maka dibutuhkan analisis bentuklahan sebagai dasar pemanfaatan potensi, menaksir ancaman bencana dan merencanakan pembangunan wilayah pesisir menuju "sustainable coastal area" di wilayah pesisir Indonesia.

\section{B. Rumusan Masalah}

Berdasarkan latar belakang diatas, rumusan masalah dari penelitian ini dapat disusun sebagai berikut:

1. Bagaimana potensi sumberdaya pada setiap karakteristik wilayah pesisir di Indonesia?

2. Bagaimana ancaman bencana pada setiap karakteristik wilayah pesisir di Indonesia?

3. Bagaimana sustainable coastal area di setiap karakteristik wilayah pesisir Indonesia.

\section{Tujuan}

Menganalisis potensi sumberdaya pada setiap karakteristik wilayah pesisir di Indonesia.

Menganalisis ancaman bencana pada setiap karakteristik wilayah pesisir di Indonesia.

Menciptakan sustainable coastal area di setiap karakteristik wilayah pesisir Indonesia. 


\section{BAB II: TELAAH PUSTAKA}

\section{A. Geomorfologi}

Geomorfologi merupakan ilmu yang mempelajari kenampakan di permukaan bumi dimulai dari bentanglahan secara luas hingga unit satuan terkecil yaitu bentuklahan (Verstappen, 1983). Geomorfologi memiliki kaitan dengan kehidupan manusia karena berhubungan dengan potensi sumberdaya yang terdapat di suatu wilayah beserta dengan ancaman bencananya. Oleh karena itu, ilmu Geomorfologi dapat digunakan sebagai dasar analisis pemanfaatan sumberdaya wilayah secara optimal dan lestari sehingga tidak mengganggu kondisi lingkungan di dalamnya.

\section{B. Bentuklahan}

Bentuklahan menurut Strahler (1983) merupakan sebuah konfigurasi permukaan bumi yang dihasilkan oleh proses alam. Sedangkan menurut Whitton (1984) bentuklahan merupakan sebuah morfologi permukaan lahan beserta dengan karakteristik di dalamnya hasil interaksi antara proses fisik dan aktivitas geologi di permukaan bumi. Sifat dan perwatakan bentuklahan mencakup 3 aspek di dalamnya, yaitu:

a. Morfologi: di dalalmnya terdapat morfografi (kesan mengenai bentuk lereng, missal: pegunungan, perbukitan, dataran) dan morfometri (berupa nilai kemiringan lereng, panjang lereng, dan bentuk lembah)

b. Material: berupa jenis batuan, material permukaan, bahan induk tanah, dan organisme di dalamnya.

c. Proses: mencakup proses yang terjadi dalam membentuk permukaan bumi baik proses endogen maupun proses eksogen.

\section{Wilayah Pesisir}

Wilayah pesisir merupakan suatu wilayah peralihan antara darat dengan laut dimana kea rah darat mencakup wilayah yang terpengaruh oleh aktivitas pasang surut dan percikan air laut, sedangkan ke arah laut hingga ke paparan benua (continental shelf) (Bentley, et al.,1992). Sedangkan menurut Soegiharto (1976), 
wilayah pesisir merupakan wilayah pertemuan antara daratan dan lautan yang mana ke arah daratan meliputi dataran baik kering maupun terendam air baik yang terpengaruh sifat-sifat laut seperti angina laut, pasang surut air laut, dan perembesan air asin. Sedangkan ke arah laut yang masih terpengaruh oleh aktivitas daratan seperti sedimentasi dan aliran air tawar maupun pengaruh aktivitas manusia (Triadmodjo,1999).

Wilayah pesisir menurut Triadmodjo (1999) berdasarkan profil pantainya dibagi ke dalam empat bagian yaitu: daerah lepas pantai (offshore), daerah pantai dalam (inshore), daerah depan pantai (foreshore), dan daerah belakang pantai (backshore). Berikut merupakan uraian dari empat bagian tersebut:

a. Daerah lepas pantai (offshore)

Wilayah dari garis batas pecah gelombang ke arah laut, seringkali disebut dengan perairan dalam karena terlepas dari paparan benua.

b. Daerah pantai dalam (inshore)

Wilayah profil pantai yang terbentang ke arah laut batas daerah depan pantai (foreshore) sampai ke bawah breaker zone

c. Daerah depan pantai (foreshore)

Wilayah yang meliputi garis pantai, daerah swash sampai dengan bagian yang tidak terlalu jauh dari garis pantai

d. Daerah belakang pantai (backshore)

Wilayah yang dibatasi oleh garis pantai kearah daratan yang dapat berupa dataran maupun perbukitan atau pegunungan.

\section{Tipologi Wilayah Pesisir}

Tipologi wilayah pesisir menurut Shepard (1937) dibagi ke dalam tipologi primer dan tipologi sekunder. Tipologi primer lebih dikontrol oleh proses-proses teresterial seperti erosi, deposisi, maupun aktivitas diatropisme dan volkanis, sedangkan tipologi sekunder didominasi oleh aktivitas organisme seperti terumbu karang dan aktivitas marin sendiri yaitu gelombang dan ombak. Tipologi wilayah pesisir di Indonesia dikelompokkan ke dalam tiga tipologi besar yaitu Land Erosion Coast, Sub Aerial Deposition Coast, dan Marine Deposition Coast. 
a. Land Erosion Coast berkembang akibat proses erosi lahan di bagian daratannya, tipologi pantai ini banyak ditemukan di wilayah karst.

b. Sub Aerial Deposition Coast terbentuk secara akumulatif akibat proses sedimentasi sungai dan banyak ditemukan di sungai dengan topografi datar dan mengalir sungai-sungai besar.

c. Marine Deposition Coast terbentuk oleh material sedimen marine dan memiliki topografi yang landau ditunjang oleh aktivitas gelombang yang besar.

\section{E. Sustainable Coastal Area}

Besarnya potensi kekayaan alam pesisir telah menimbulkan berbagai permasalahan lingkungan hidup seperti kelebihan tangkap (over fishing) di sektor perikanan, perusakan hutan mangrove, terumbu karang dan padang lamun serta abrasi pantai dan gelombang pasang hingga masalah kerusakan akibat bencana alam seperti tsunami. Pengelolaan sumberdaya wilayah pesisir secara optimal dan berkelanjutan hanya dapat diwujudkan melalui pendekatan terpadu dan holistik. Pengelolaan wilayah pesisir terpadu dinyatakan sebagai proses pemanfaatan sumberdaya pesisir serta ruang yang memperhatikan aspek konservasi dan keberlanjutannya (Cicin-Sain dan Knect, 1998)

Wilayah pesisir memiliki nilai yang strategis dalam potensi sumberdaya yang besar namun memiliki ancaman yang besar terhadap kerusakan baik oleh aktivitas alami (bencana alam) maupun oleh aktivitas manusia. Diperlukan strategi pengelolaan yang terpadu untuk mendukung pengelolaan pesisir yang berkelanjutan, salah satunya dapat dilakukan dengan mengetahui karakteristik dari wilayah pesisir itu sendiri. Suatu kegiatan dikatakan berkelanjutan apabila pengelolaannya dilakukan untuk menunjang prinsip ekonomis, ekologis, dan social politik (Fabianto dan Pieter, 2014).

BAB III: METODE PENULISAN 


\section{A. Wilayah Kajian}

Pesisir di Indonesia dapat dikategorikan menjadi tiga, yaitu marine deposition coast, subaerial deposition coast, dan karst coast. Ketiga karakteristik tersebut merupakan yang paling dominan di Indonesia. Marine deposition coast membentang sepanjang pesisir selatan Jawa, barat Sumatera, dan Bali yang dicirikan dengan pengendapan material pasir oleh gelombang laut. Subaerial deposition coast terdapat di sepanjang utara Jawa, timur Sumatra, Kalimantan, dan selatan Papua yang dicirkan dengan pengendapan material oleh aliran sungai. Karst coast terdapat di Jawa(karst Gunungsewu, Gombong), Kalimantan, Bali, dan Papua yang dicirikan dengan material penyusun batugamping yang berkembang.

Setiap karakteristik pesisir tersebut akan dikaji satu daerah yang menjadi garis besar penelitian. Hal ini dilakukan karena satu karakteristik pesisir mempunyai sifat khas yang dapat mewakilinya. Pengkajian terhadap marine deposition coast dilakukan di pesisir Bantul (Pantai Samas - Pantai Pandansismo), subaerial deposition coast dilakukan di pesisir Demak, dan karst coast dilakukan di pesisir Gunungkidul.

\section{B. Jenis Penelitian}

Penelitian ini menggunakan metode pengambilan data kuantitatif dengan analisis diskriptif.

\section{Teknik Pengumpulan Data}

Pengambilan data di penelitian ini dilakukan dengan tiga cara, yaitu: survei lapangan, studi literatur, dan analisis citra satelit. Data yang dikumpulkan adalah morfologi, proses geomorfologi, dan material batuan dari setiap karakteristik pesisir di wilayah kajian. Data tersebut digunakan untuk menentukan satuan bentuklahan yang setelahnya digunakan sebagai dasar analisis potensi sumberdaya alam dan bencana.

Studi literatur dan analisis citra satelit merupakan hal yang pertama kali dilakukan di penelitian ini. Citra satelit yang digunakan adalah citra google earth tahun 2015. Lieteratur yang digunakan berupa jurnal dan skripsi. Melalui kedua 
proses tersebut dapat dieketahui secara tentatif satuan bentuklahan dan potensis sumberdaya alam maupun bencana di wilayah kajian.

Survei lapangan dilakukan untuk memvalidasi analisis tentatif yang telah dilakukan. Pengamatan lapangan dilakukan berdasarkan titik survei/sampel yang sebelumya telah ditentukan. Pengambilan data dilapangan dilakukan dengan mengisi ceklist yang pada dasarnya berisi morfologi, proses geomorfologi, dan material penyusun di setiap titik pengamatan.

\section{Analisis Data}

Analisis diskriptif dilakukan terhadap data satuan bentuklahan di setiap karakteristik pesisir. Satuan bentuklahan tersebut dibuat berdasarkan data morfologi, proses geomorfologi, dan maerial penyusun. Analisis tersebut menjelaskan potensi sumberdaya alam dan potensi bencana yang ada di setiap karakteristik pesisir. Hasil analisis ditampilkan dalam bentuk tabel dan peta. Potensi sumberdaya alam dan bencana tersebut selanjutnya akan digunakan sebagai dasar rekomendasi penyusunan sustainable coastal area.

BAB IV: ANALISIS DAN SISTESIS 


\section{A. Karst Coast}

\section{a. Karakteristik Pesisir}

Pesisir bertipe karst sangat dipengaruhi oleh material batugamping yang telah membentuk sistem karst. Batugamping yang mempunyai sifat mudah larut menjadikan sistem ini mempunyai cirikhas seperti aliran permukaan yang jarang, terbentuknya sungai bawah tanah dan sistem perguaan, serta lapisan tanah yang tipis. Sifat-sidat tersebut memengaruhi keadaan pesisir di kawasan karst.

Menurut Cahyadi(2013), karakteristik pesisir di karst Gunungkidul terdiri dari wave erosion coast, marine deposition coast, dan structurally shaped coast. Secara lebih umum, Santosa (2011) menjabarkan profil pesisir karst terdiri dari tiga jenis, yaitu: pantai bercliff, pantai bergisik saku, dan pantai bergisik saku dengan lembah karst. Hasil analisis menunjukkan bahwa pada dasarnya kedua klasifikasi diatas sama, namun memiliki perbedaan di dalam pendekatan yang digunakan. Penelitian ini menggabungkan klasifikasi antara Cahyadi(2013) dan Santosa(2011). Hasil karakteristik pesisir karst Gunungkidul dapat dilihat pada Gambar 2.

Wave erosion coast dan marine deposition coast merupakan karakteristik yang seringkali ditemui bersamaan dalam satu pesisir. Perbedaan utama dari kedua karakteristik ini adalah tenaga geomorfologi yang bekerja. Tenaga erosi gelombang laut merupakan yang utama pada wave erosion coast, sehingga mengahasilkan bentukan seperti sea cave, stack, dan notch (Gambar 1). Sementara itu, tenaga deposisi gelombang laut merupakan yang paling dominan pada marine deposition coast, sehingga menghasilkan bentukan pantai bergisik saku. 


\section{Gambar 1: Bentukan wave erosion coast}

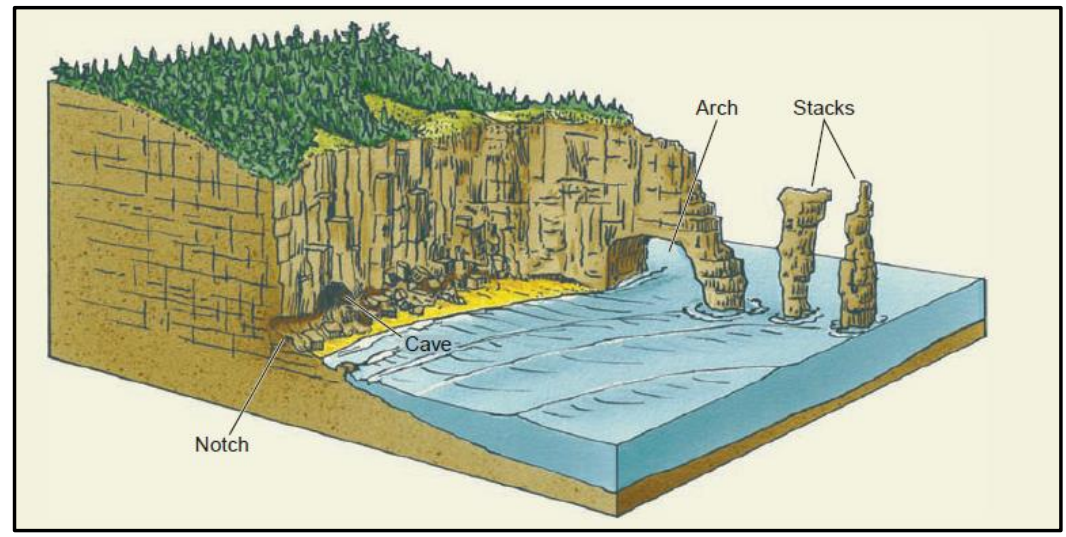

Sumber: Strahler, 2011

Gambar 2: Karakteristik pesisir karst

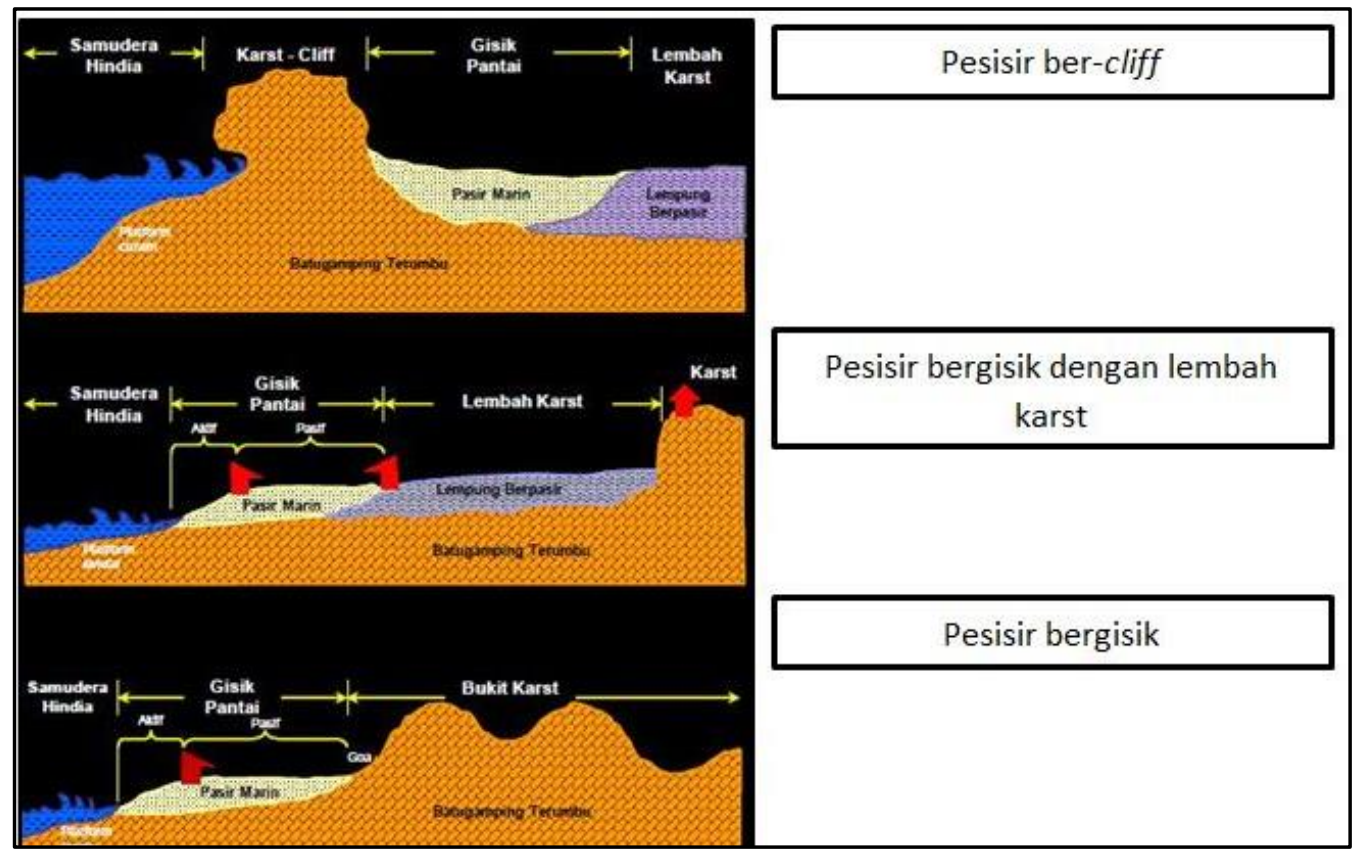

Sumber: Santosa, 2010

Structurally shaped coast merupakan pesisir dengan ciri laut yang langsung berbatasan dengan tebing terjal (gambarxx). Bentukan ini dikontrol proses pengangkatan oleh tenaga endogen. Batugamping yang terangkat membentuk sesar dengan pelurusan tertentu. 


\section{b. Potensi Sumberdaya Alam}

Pesisir bertipe karst memiliki karakteristik unik berupa gisik berwarna putih, runtuhan batugamping, bukit karst, dan muara sungai bawah tanah. Bentukan unik tersebut menjadikan banyak orang tertarik mengunjunginya. Oleh karena itu, pesisir bertipe karst merupakan suatu potensi wisata yang sangat besar. Pesisir di Raja Ampat (Papua) dan Gunungkidul merupakan contoh nyata. Pariwisata di Gunungkidul mampu menghasilkan PAD (Pendapatan Asli Daerah) mencapai 14 miliar pada tahun 2014 (www.antaranews.com).

\section{Tabel 1: Potensi Sumberdaya Alam Pesisir Karst}

\begin{tabular}{|c|c|l|}
\hline No & Potensi & \multicolumn{1}{c|}{ Keterangan } \\
\hline 1 & Pariwisata & $\begin{array}{l}\text { Pantai karst memiliki karakteristik } \\
\text { menarik, seperti: pasir putih, bukit karst, } \\
\text { tebing, sungai bawah tanah. }\end{array}$ \\
\hline 2 & $\begin{array}{c}\text { Perikanan } \\
\text { Tangkap }\end{array}$ & $\begin{array}{l}\text { Lautan Indonesia menyimpan sumberdaya } \\
\text { ikan yang melimpah. Hal ini perlu } \\
\text { dimaksimalkan sebagai usaha untuk } \\
\text { meningkatkan produktifitas. }\end{array}$ \\
\hline 3 & Jasa & $\begin{array}{l}\text { Sektor pariwisata akan memicu timbulnya } \\
\text { sektor jasa, seperti: pemandu, pedagang, } \\
\text { perhotelan/penginapan, warung makan. }\end{array}$ \\
\hline
\end{tabular}

Sumber: analisis, 2016

Pariwisata di pesisir karst terdiri dari berbagai macam kegiatan, seperti berkemah, menikmati ombak, melihat sunset dan sunrise, memancing, snorkeling. Kegiatan pariwisata tersebut tentunya dapat meningkatkan ekonomi masyarakat sekitar maupun pemerintah setempat. Sektor pariwisata dapat memicu tumbunya sektor jasa seperti pemandu, penjual makanan, homestay. Pesisir karst juga mempunyai potensi lain seperti perikanan, olahraga(climbing), sumber air (sungai bawah tanah) (Tabel 1), meskipun kegiatan pariwisata tetap merupakan primadona.

Potensi bencana yang terdapat di pesisir karst adalah tsunami, abrasi, kekeringan, dan longsor tebing (Tabel 1). Tsunami merupakan ancaman yang 
hampir terdapat di seluruh pesisir Indonesia sebagai akibat adanya jalur subduksi. Meskipun demikian, karakteristik pesisir karst dengan adanya bukit karst dapat digunakan untuk meminimalisir dampak yang terjadi. Jalur evakuasi menuju bukitbukit karst terdekat merupakan cara sederhana yang dapat berakibat besar.

\section{c. Potensi Bencana}

Tabel 2: Potensi Sumberdaya Alam Pesisir Karst

\begin{tabular}{|c|c|l|}
\hline No & Bencana & \multicolumn{1}{c|}{ Keterangan } \\
\hline 1 & Tsunami & $\begin{array}{l}\text { Gelombang tsunami merupakan } \\
\text { ancaman di seluruh pesisir } \\
\text { Indonesia sebagai akibat adanya } \\
\text { zona subduksi. }\end{array}$ \\
\hline 2 & Abrasi & $\begin{array}{l}\text { Ancaman abrasi semakin nyata } \\
\text { sebagai akibat adanya kenaikan } \\
\text { muka air laut. Abrasi dapat } \\
\text { merusak fasilitas-infrastuktur dan } \\
\text { menyempitkan daratan. }\end{array}$ \\
\hline 3 & Longsor & $\begin{array}{l}\text { Batuan karst memiliki karakteristik } \\
\text { mudah terlarut, hal ini } \\
\text { menyebabkan longsor tebing } \\
\text { mudah terjadi. }\end{array}$ \\
\hline 4 & Kebing & $\begin{array}{l}\text { Karakteristik karst adalah sumber } \\
\text { air permukaan yang sedikit, namun } \\
\text { memilki air bawah permukaan yang } \\
\text { melimpah. Sulitnya menjangkau air } \\
\text { bawah permukaan ini berpotensi } \\
\text { menyebabkan kekeringan. }\end{array}$ \\
\hline
\end{tabular}

Sumber: analisis, 2016

Longsor tebing dan abrasi merupakan dua hal yang saling terkait. Sifat batugamping yang mempunyai porositas sekunder dapat memicu longsornya tebing karst. Tebing longsor terjadi di Pantai Sadranan pada Juni 2015 yang menewaskan tiga orang wisatawan (www.tempo.co).

Bentuklahan karst memiliki potensi kekeringan akibat minimnya aliran permukaan yang ada. Meskipun demikian, karst pada dasarnya memiliki sumber air melimpah yang tersimpan dalam sungai bawah tanah. Permasalahan selama ini adalah pengangkatan air tersebut untuk dimanfaatkan merupakan hal sulit. Oleh 
karena itu, pariwisata yang terus meningkat harus diimbangin dengan pemafaatan air di karst sebagai fasilitas wisata.

\section{d. Sustainable Coastal Area}

Pesisir berkelanjutan merupakan suatu konsep yang digunakan untuk memaksimalkan potensi yang ada. Maksud konsep ini secara sederhana adalah untuk mengoptimalkan sumberdaya yang ada saat ini tanpa mengorbankan kepentingan masa depan. Pesisir berkelanjutan di kawasan karst dapat dicapai salah salah satunya dengan cara menerapkan zonasi wilayah pesisir. Zonasi wilayah pesisir di kawasan karst dapat diihat pada Gambar 3.

Peta zonasi pesisir berkelanjutan ini mengambil contoh kajian di Pesisir Baron, Gunungkidul. Hasil analisis menunjukkan bahwa wilayah kajian terdiri dari 6 zona, yaitu: zona ekonomi, zona konservasi, zona rekreasi, dan zona lepas pantai. Zona tersebut diklasifikasikan berdasarkan bentuklahan yang berbeda.

Pesisir Baron merupakan tipe pesisir karst yang memiliki gisik, tebing karst, dan bukit karst. Tipe pesisir karst ini membentuk bentuklahan khas yang selanjutnya digunakan sebagai dasar zonasi. Samudera Hindia

didefinisikan sebagai lepas pantai pada zonasi ini. Bentuklahan pantai yang memiliki proses pasang surut air laut didefinisikan sebagai zona rekreasi. Gisik pantai hasil endapan gelombang laut diklasifikasikan menjadi zona ekonomi. Bukit karst yang berada di sekitar obyek pariwisata Baron diklasifikasikan sebagai zona konservasi.

Zona lepas pantai merupakan Samudera Hindia yang berbatasan langsung dengan Pesisir Baron. Peruntukkan utama zona ini adalah sebagai wilayah penangkapan ikan. Aktifitas penangapan ikan yang dapat dilakukan adalah dengan menggunakan kapal oleh nelayan atau dengan cara sederahana menggunakan alat pancing.

Zona rekreasi yang direncanakan menempati bentuklahan pantai. Pemanfaatan zona ini utamanya digunakan sebagai tempat bersantai dan bermain. Zona ini dapat didirikan fasilitas nonpermanen untuk menunjang aktifitas tersebut. 
Fasilitas ini dapat berupa payung atau gazebo tempat bersantai. Fasilitas nonpermanent direkomendasikan karena proses yang terjadi di area ini berupa pasang surut air laut. Pantai karst memiliki keunikan berupa pemandangan bukit karst yang indah dan pasir berwarna putih, sehingga mendukung untuk dijadikan kegiatan bersantai.

\section{Gambar 3: Peta Zonasi Sustainbele Coastal di Pesisir Baron}

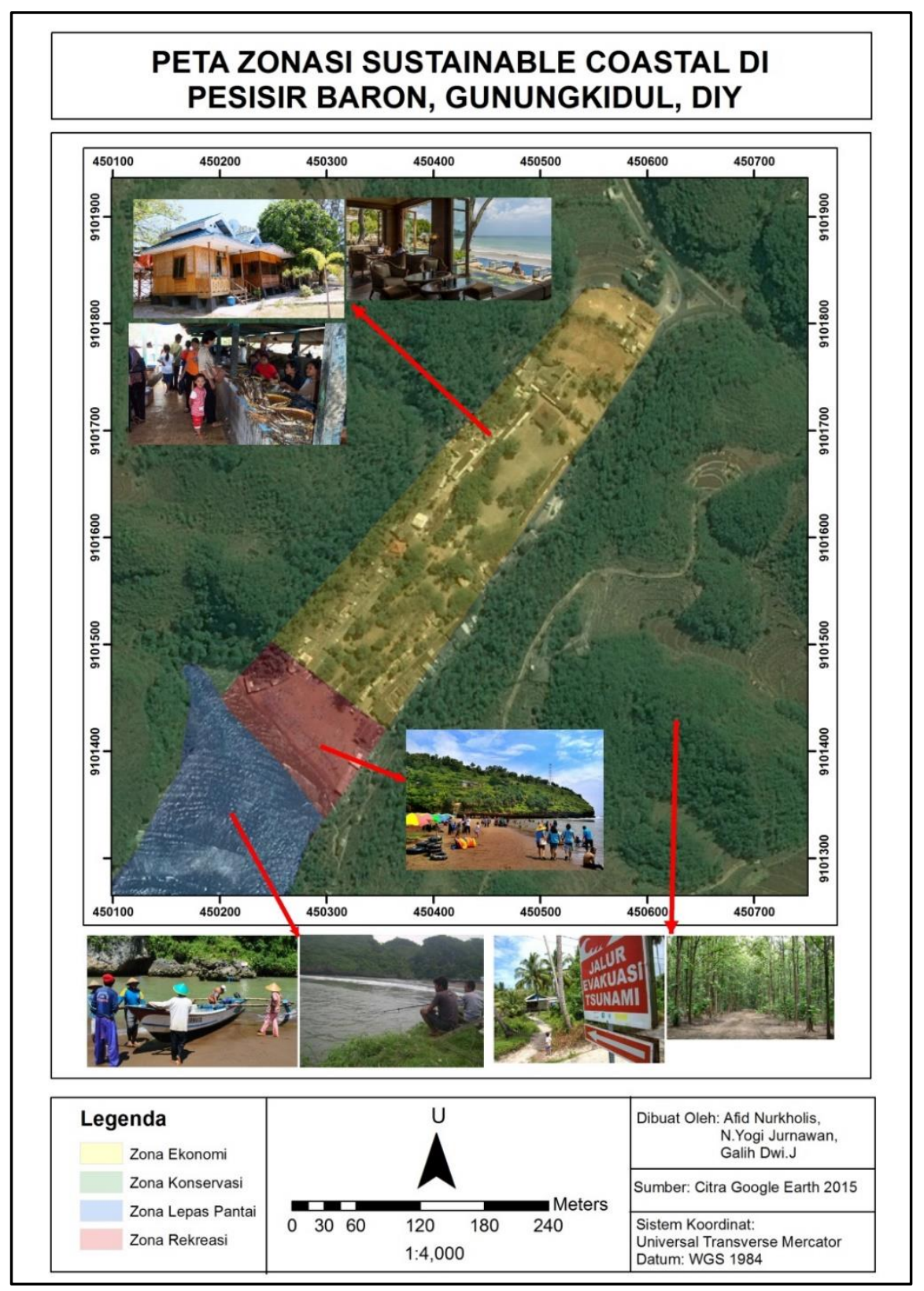

Sumber: Pengolahan Data, 2016 
Zona ekonomi direkomendasikan berada di kawasan gisik yang sudah tidak terpengaruh aktifitas air laut. Zona ekonomi pada Gambar 3 berada pada jarak 500 meter dari garis pantai. Pemanfaatan zona ini direkomendasikan untuk perdagangan (pasar,warung,supermarket), penginapan (losmen, cottage, homestay), dan rumah makan. Bangunan permanen dapat dibangun diwilayah ini mengingat kerawanannya yang relatif rendah dibandingkan kawasan pantai. Zona ini sebagai kawasan pendukung wisata pantai. Infrastuktur dan fasilitas yang baik akan menjadikan wisata pantai berkembang. Aktifitas wisata yang berkembang akan menjadikan produktifitas atau pendapatan masyarakat meningkat.

Zona konservasi berada di bentuklahan bukit-bukit karst. Bukit karst terbentuk sebagai akibat pelarutan oleh air. Karakteristik bentukan ini adalah tanah tipis, air permukaan rendah, dan topografi yang lebih tinggi dari sekitarnya. Oleh karena itu, pemanfaatan zona ini direkomendasikan sebagai hutan jati. Pohon jati merupakan vegetasi yang tahan terhadap kekurangan air dan disisi lain memiliki nilai ekonomi tinggi.

Pesisir memiliki potensi bahaya berupa gelombang tsunami. Adanya bukit karst merupakan suatu potensi yang dapat digunakan sebagai area evakuasi ketika tsunami terjadi. Bukit karst yang memiliki elevasi jauh lebih tinggi dari sekitarnya merupakan area evakuasi yang efisien. Kerentanan di wilayah pesisir karst dapat diturunkan dengan mengoptimalkan potensi ini. Selain itu, pelatihan evakuasi juga perlu dilakukan.

\section{B. Marine Deposition Coast}

\section{a. Karakteristik Pesisir}

Marine Deposition Coast memiliki karakteristik pesisir yang terbentu oleh proses deposisi material marine. Kondisi topografinya relatif landai dan mempunyai aktivitas gelombang dan ombak laut yang besar sehingga proses deposisi material marine nya berlangsung intensif. Pesisir dengan tipologi ini memiliki bentuklahan yang sangat beragam akibat pengaruh dari aktivitas gelombang dari laut dan 
aktivitas di daratan sehingga menghasilkan bentukan-bentukan seperti gisik, beting gisik, laguna, estuary, dan dataran fluviomarin.

Di pesisir selatan Bantul terdiri atas banyak pantai yang sudah dimanfaatkan baik untuk aktivitas pariwisata maupun perikanan (laut dan tambak udang). Pesisir selatan bantul di bagian timur berbatasan dengan escarpment baturagung, di bagian barat pesisir Kulonprogo yang karakteristik pesisirnya relative sama, di bagian utara terdapat Gunungapi Merapi disertai dengan sungai-sungainya yang berhulu di Pesisir Selatan Bantul, dan di bagian selatan langsung berbatasan dengan Samudera Hindia. Letak pesisir bantul yang demikian kompleks tersebut menyebabkan kenampakan geomorfologisnya beragam pula yang berarti potensi sumberdaya dan ancaman bencananya juga beragam pula.

Pesisir selatan bantul memiliki gisik berwarna hitam yang berasal dari proses deposisi material Gunungapi Merapi yang dialirkan melalui beberapa sungai besar seperti Sungai Opak dan Sungai Progo. Keunikan kenampakan alam yang terdapat di Pesisir Selatan Bantul tersebut menyebabkan potensi dan ancaman yang beragam, seperti diuraikan sebagai berikut:

\section{b. Potensi Sumberdaya Alam}

\section{- Wisata}

Terletak pada lokasi yang 'strategis' karena bentukan-bentukan di sekitarnya yang sangat beragam menyebabkan proses yang berlangsung Pesisir Selatan Bantul juga unik sehingga menghasilkan bentukan yang unik-unik pula. Kenampakan geomorfologi unik yang digunakan sebagai destinasi wisata di Pesisir Bantul antara lain adalah Bukit Parangendog di Perbukitan Baturagung yang digunakan sebagai lokasi wisata paralayang serta menikmati laut saat pagi hari dan saat matahari tenggelam.

Topografi yang datar dan gisik yang cukup luas dapat digunakan pengunjung wisata untuk berintraksi dengan ombak di pantai Parangtritis di bagian timur hingga Pantai Pandansimo. Hal lain yang dapat dilakukan adalah bermain layang-layang dikarenakan tidak terdapatnya penghalang antar pantai sehingga leluasa. Potensi wisata lainnya berupa rumah makan dari hasil perikanan laut di 
bebrapa pantai, seperti Pantai Depok dan Pantai Kuwaru. Sedangkan jenis daya tarik wisata lainnya berupa wisata religi dan budaya seperti tempat-tempat yang dianggap keramat di Pantai Parangkusumo dan Budaya Labuhan di Pantai Parangtritis.

\section{- Perikanan dan Tambak Udang}

Menurut website http://investasi.bantulkab.go.id/ hasil tangkapan laut di Pesisir Selatan Bantul mencapai 541.314 ton pada tahun 2013 dengan jenis hasil tangkapan berupa ikan bawal, kakap, layur bawal, cakalang, dan lain sebagainya. Besarnya potensi perikanan di Bantul karena letaknya yang berbatasan langsung dengan Samudera Hindia sehingga arus pergerakan ikan banyak terdapat di tempat tersebut.

Selain hasil perikanan dari laut di Bantul banyak dikembangkan tambak udang oleh masyarakat sekitar, bahkan karena karakteristik fisik seperti lahan dan airnya sesuai membuat banyak petani dan nelayan beralih profesi menjadi penambak udang karena hasilnya lebih besar. Namun tambak udang mendapatkan banyak pertentangan karena mengancam ekosistem di sekitarnya baik vegetasi maupun kondisi fisiknya.

\section{- Pertanian}

Bentukanlahan di Pesisir Bantul yang mempunyai produktivitas tinggi untuk pertanian terletak pada dataran fluviomarin karena tekstur tanahnya tidak hanya pasir dan telah bercampur dengan lempung akibat proses pengendapan dari tenaga fluvial di sekitarnya. Pemenuhan kebutuhan air untuk irigasinya diambilkan dari airtanah yang diperoleh pembuatan dari sumur gali di sekelilingnya.

\section{- Gumuk Pasir}

Gumuk Pasir di Pesisir Selatan Bantul terbentuk akibat dari proses Aeolian yaitu pengangkutan material halus pasir oleh tenaga angin hingga membuat gundukan dan merupakan kenampakan yang sangat unik. Selain menarik untuk kegiatan wisata, gumuk pasir memiliki banyak fungsi ekologis sebagai akuifer local airtanah tawar, penyangga dari intrusi air laut, serta peredam saat terjadinya tsunami. Jenis gumuk pasir yang terdapat di Pesisir Selatan Bantul antara lain adalah tipe Barchan dan Ripple. Namun di balik segala keunikannya, Gumuk Pasir 
memiliki beberapa ancaman seperti penambangan sehingga dapat merusak keberadaan gumuk pasir itu sendiri.

\section{- Energi Terbarukan Angin dan Sinar Matahari}

Dikarenakan letak geografisnya yang berhadapan langsung dengan Samudera Hindia maka angin yang berhembus kencang dan terik matahari menjadi hal yang selalu ditemukan di Pesisir Bantul. Oleh karena kedua potensi angina dan sinar matahari tersebut mulai dilakukan perintisan Pemabngkit listrik tenaga Hibrid di Kawasan Pantai Baru. Suplai energy listrik tersebut dapat digunakan untuk pertanian dan perdagangan (warung-warung).

\section{c. Potensi Bencana}

\section{- Abrasi}

Kondisi gisik yang cukup luas serta aktivitas gelombang laut yang besar dikarenakan berbatasan langsung dengan Samuder Hindia menyebabkan proses abrasi pantai sering terjadi di Pesisir Selatan Bantul. Abrasi parah terjadi pada tahun 2013-2014 yang menerjang Pantai Kuwaru dan Pantai Samas hingga menyebabkan rumah-rumah penduduk dan kawasan wisatanya hancur diterjang ombak. Hal tersebut disebabkan karena memang lokasi rumah yang terlalu dekat dengan bibir pantai dan juga proses alam seperti gaya tarik bulan sehingga air pasang. Aktivitas manusia yang mendukung terjadinya abrasi adalah penambangan pasir di bagian hulu sungai yang membawa material volkanis sehingga tidak terdeposisikan di pantai dan menyebabkan jumlah gisik berkurang.

\section{- Tsunami}

Terletak di perbatasan Lempeng benua dan Lempeng samudera menyebabkan aktivitas geologi tidak dapat terlepas di Pesisir Selatan Bantul sehingga ancaman gempa bumi dapat terjadi sewaktu-waktu seperti yang terjadi pada tahun 2006. Namun jika pusat gempa terdapat di tengah laut maka dapat memicu terjadinya tsunami di wilayah Pesisir Selatan Bantul. Kondisi topografi yang landau juga meningkatkan kerawanan terjadinya tsunami karena tempat yang aman sulit dijangkau. 


\section{- $\quad$ Rip Current}

Berbatasan langsung dengan Samudera Hindia maka dapat diidentifikasi bahwa kondisi topografi bawah laut Pesisir Selatan Bantul curam dan banyak terdapat palung. Kondisi gelombang laut yang kuat, angin yang kuat, banyaknya palung, serta topografi bawah laut yang curam dapat memicu terjadinya peristiwa rip current yaitu proses dimana arus kembali dengan sangat cepat sehingga dapat membahayakan pengunjung di area wisata.

\section{- Intrusi Air Laut}

Dapat terjadi akibat penggunaan airtanah di wilayah peisir yang dilakukan sangat intensif untuk memenuhi kebutuhan baik domestic mauoun pariwisata. Intrusi air laut sendiri memiliki definisi Masuknya air laut ke dalam tubuh akuifer di wilayah pesisir, baik melalui permukaan maupun bawah permukaan, yang menyebabkan airtanah menjadi asin. Material pesisir bantul yang terdiri atas pasir menyebabkan pori-porinya besar sehingga saat terjadinya pasang maka air laut dapat masuk ke dalam tanah dan campur dengan airtanah.

\section{d. Sustainable Coastal Area}

Penyongsongan wilayah kepesisiran yang dapat dimanfaatkan dengan mengedepan aspek keberlanjutan dilakukan dengan melakukan zonasi wilayah kepesisiran berdasarkan bentukanlahan yang terdapat pada masing-masing tipologi kepesisiran yang dikaji. Tipologi pesisir marine deposistion coast diklasifikan ke dalam empat zona yaitu zona ekonomi pertanian, zona ekonomi tambak, zona konservasi, dan zona rekreasi. Pembagian zonasi kepesisiran tersebut dimaksudkan agar pemanfaatan sumberdaya dapat dilakukan secara optimal dan dapat dimanfaatkan secara lestari dan tidak mengganggu atau merusak ekosistem di pesisir tersebut.

Berdasarkan jarak dari laut, zonasi pertama yang akan dibahas adalah zona rekreasi yang berada pada bentuklahan pantai (shore). Pemilihan shore sebagai zona rekreasi berdasarkan pada kenampakan geomorfologi yang terdapat pada lokasi tersebut, antara lain adalah gisik yang berupa pasir besi yang merupakan hasil 
deposisi material vulkanis Gunungapi Merapi, pasang surut air laut disertai dengan deburan ombak dan muara dari Sungai Progo di bagian barat pesisir Bantul. Fenomena lain yang dapat menjadi nilai jual dari Pesisir Selatan Bantul adalah saat matahari terbit dan matahari terbenam sehingga dapat dimanfaatkan para wisatawan untuk menikmati waktu. Topografi pantai yang datar membuat para wisatawan dapat memanfaatkan banyak lokasi untuk menikmati pantai tersebut.

Zonasi selanjutnya adalah Zona Ekonomi Tambak yang berada di perairan payau akibat bertemunya muara Sungai Progo dengan ombak di Pesisir Selatan Bantul. Perairan payau digunakan untuk budidaya tambak udang yang mana memang dapat berkembang dengan baik di wilayah perairan payau. Zona Ekonomi tambak udang tersebut menurut www.harianjogja.com tanggal 19 Agustus 2015, satu kolam tambak udang dapat mendapatkan keuntungan sebesar 150 juta hingga 200 juta rupiah sekali panen. Hal tersebut menjadi dasar mengapa dalam kurang lebih satu decade terakhir banyak tambak udang menjamur di Pesisir Selatan Bantul.

Zonasi berikutnya merupakan Zona Konservasi yang lokasinya berada di bagaian gisik pantai namun tidak terkena aktivitas pasang surut gelomabng laut saat kejadian normal. Bentuk konservasi yang dapat dilakukan di Pesisir Selatan Bantul berupa penanaman Pohon Cemara Udang yang mempunyai banyak manfaat. Yang paling utama dapat digunakan untuk menahan laju abrasi yang berjalan intensif di wilayah pesisir tersebut, selanjutnya dapat digunakan untuk menahan laju angin laut yang menuju ke daratan. Fungsi yang dapat terjadi saat kejadian ekstrem adalah untuk menahan bencana tsunami yang dapat terjadi sewaktu-waktu. Konservasi yang dapat diterapkan selain fungsi lingkungan adalah fungsi konservasi biota yaitu penakaran tukik.

Zona terakhir adalah Zonasi Ekonomi Pertanian yang terletak di bentuklahan Dataran Fluviomarin. Dataran fluviomarin dapat digunakan untuk lahan pertanaian karena karakteristik lahannya bukan hanya berupa pasiran namun karena terpengaruh aktivitas pengendapan fluvial maka tekstur lahannya berupa campuran antara pasir, debu, dan lempung sehingga mendukung untuk aktivitas 
pertanian. Selain itu diakibatkan karena terpengaruh aktivitas fluvial maka ketersediaan airnya baik air permukaan maupun airtanah cukup melimpah.

Gambar 4: Peta Zonasi Sustainbele Coastal di Pesisir Bantul

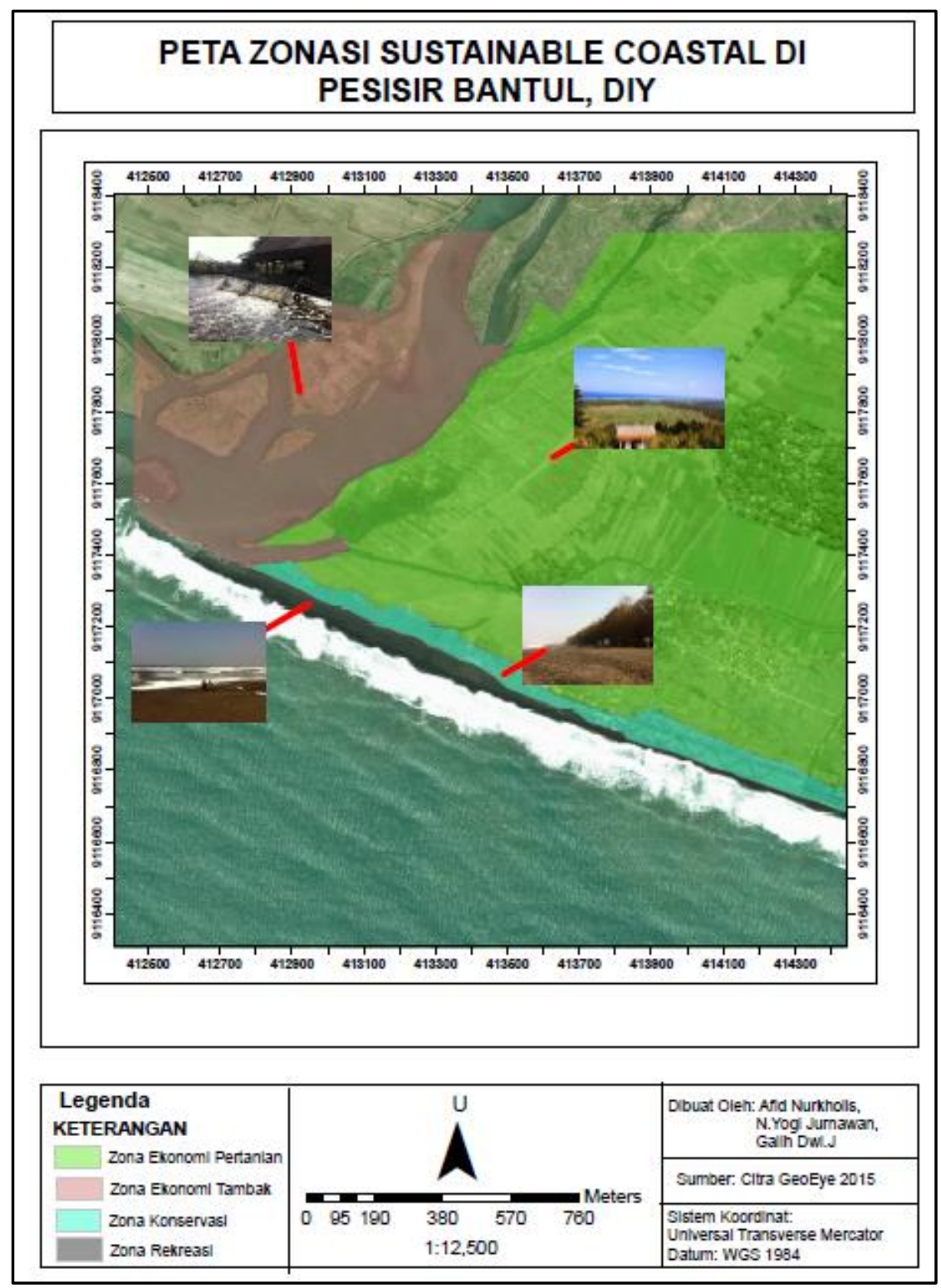

Sumber: Pengolahan data, 2016 


\section{Subaerial Deposition Coast}

\section{a. Karakteristik Pesisir}

Wilayah pantai di pesisir Kabupaten Demak berdasarkan citra satelit (2009) memiliki panjang garis pantai 72,14 Km. Potensi ekonomi dan lingkungan tersebut diantaranya adalah wisata bahari, penangkapan ikan, budidaya perikanan, pelabuhan rakyat dan lain sebagainya. Wilayah pantai di Kabupaten Demak memanjang dari selatan ke utara sehingga pada musim barat gelombang menghantam pantai Kabupaten Demak secara tegak lurus yang berakibat sebagian pantai Kabupaten Demak mengalami abrasi. Faktor-faktor alam yang berpengaruh antara lain arus laut, gelombang, kondisi morfologi, litologi dan vegetasi yang tumbuh di pantai.

Pesisir subaerial deposition coast didominasi oleh proses deposisi material halus. Selain itu, karakteristik ombak dan gelombang di pantai utara jawa yang tenang sangat mendukung proses deposiis tersebut. Material yang terbawa oleh aliran sungai yang bermuara di laut kemudian diendapkan oleh tenaga sungai ataupun tenaga air laut. Asal material deposisi pada pesisir Demak sangat dipengaruhi oleh keberadaan beberapa gunungapi yang aktif pada masa lampau yaitu Gunungapi Muria, Gunungapi Genuk, dan Gunungapi Patiayam. Kompleks gunung api tersebut mulai beraktifitas sejak kala Pliosen hingga kala holosen. Sebelum abad ke-17, perairan di sekitar Gunungapi Muria merupakan perairan yang agak lebar dan dapat dilayari oleh kapal-kapal dagang kerajaan Demak (Sunarto,dkk., 2013). Tingkat pengikisan yang tinggi gunungapi Muria menyebabkan material-material gunungapi tersebut terbawa dan terendapkan hingga pesisir Demak.

Morfologi umum pesisir Demak didominasi oleh dataran fluviomarin dan rataan pasang surut. Dataran fluviomarin dipengaruhi oleh proses fluvial dan marin. Proses fluvial yang terjadi sebagian besar dipengaruhi oleh aliran sungai berupa transportasi material dan sebagai agen pengendapan material. Proses marin yang terjadi lebih banyak sebagai agen pengendapan material, dimana laut utara jawa memiliki arus dan gelombang yang relative tenang dibanding laut selatan jawa. 
Dataran fluviomarin lebih banyak didominasi oleh permukiman dan lahan pertanian sawah, mengingat wilayah ini memiliki topografi datar, kaya air dan memiliki tanah yang subur. Darah rataan pasang surut sangat dipengaruhi oleh aktivitas marin berupa gelombang pasang dan gelombang surut. Daerah ini terletak pada ujung utara atau bagian yang berbatasan langsung dengan laut lepas. Daerah rataan pasang surut ini jarang digunakan sebagai lahan produktif seperti permukiman dan sawah karena sangat rawan bencana banjir rob. Daerah ini sebagian besar didominasi oleh tanaman mangrove yang sangat cocok hidup di daerah yang tergenang dan material berupa lumpur.

\section{b. Potensi Sumberdaya Alam}

\section{- Potensi Sumberdaya Lahan Pertanian}

Potensi sumberdaya pesisir terbagi menjadi potensi sumberdaya alam dan manusia. Potensi sumberdaya alam pesisir dikontrol oleh faktor bentuklahan yang ada pada atau tipologi pesisir masing-masing. Pada pesisir dengan tipologi subaerial deposition coast memiliki sumberdaya alam yang cukup baik. Sumberdaya lahan yang ada cukup baik, karena berada pada topografi landai hingga datar dengan kandungan tanah yang subur karena berasal dari material alluvium yang terdiri dari lempung dan material rombakan vulkanik. Hal ini menyebabkan pada wilayah pesisir Demak banyak terdapat lahan pertanian sawah.

\section{- Potensi Sumberdaya Air untuk Tambak dan Domestik}

Potensi sumberdaya air pada pesisir Demak bisa dikatakan cukup baik. Dengan curah hujan rata-rata tahunan 1500-2200 mm/tahun maka cukup untuk menjadi potensi air meteorologis. Curah hujan yang ada merupakan input dari sistim hidrologi yang mengontrol potensi sumberdaya air permukaan dan airtanah. Jumlah sungai yang cukup banyak menjadi wadah bagi air hujan untuk selanjutnya dimanfaatkan oleh masyarakat untuk memenuhi kebutuhan air. Potensi sumberdaya airtanah dikontrol oleh karakter akuifer, permeabilitas dan porositas batuan, dan lereng. Karakteristik akuifer yang ada pada pesisir Demak cukup baik karena terdiri batuan endapan alluvial yang porus, mempunyai kemampuan menyimpan dan meneruskan air yang tinggi. Permeabilitas dan porositas batuan di pesisir Demak 
sangat mendukung dalam meloloskan air yang berasal dari aliran permukaan menuju dalam tanah dan menjadi airtanah.

\section{- Potensi Sumberdaya untuk Permukiman dan Industri}

Kondisi lahan dan air yang sedemikian rupa kemudian mempengaruhi dalam pemanfaatan lahan yang ada. Sebagian besar lahan di pesisir demak dimanfaatkan untuk lahan pertanian sawah. Selain itu dapat dijumpai budidaya perikanan tambak dan budidaya perikanan tangkap. Topografi yang relatif datar, tersedianya akses, dan mudah nya mendapatkan air maka banyak juga ditemui kompleks permukiman penduduk.

Selain itu terdapat pula banyak kompleks industry kecil hingga besar. Alasan banyaknya aktivitas industri karena tenaga kerja yang murah, akses yang mudah dan kemudahan dalam memindahkan barang karena dekat dengan pelabuhan tanjung emas Semarang yang menjadi pintu masuk aliran barang dan jasa menuju luar jawa.

\section{- Potensi Sumberdaya Ekosistem Mangrove}

Ekosistem mangrove yang ada di pesisir Demak bisa menjadi aset yang berharga bagi kelangsungan kehidupan masyarakat pesisir. Mangrove sangat penting dalam menjaga ekosistem pesisir. Tanaman mangrove bisa menjadi tempat ikan-ikan bernaung dan mencari makan. Selain itu, adanya tanaman mangrove bisa menjadi agen untuk mengatasi masalah abrasi pantai yang semakin parah terjadi. Dengan adanya tanaman mangrove, daratan yang ada akan terlindungi dari ancaman banjir rob, kenaikan muka air laut, dan tsunami. Tanaman mangrove juga mempunyai nilai ekonomis yang cukup tinggi yakni bisa dijadikan kayu bakar, briket, kerajinan tangan dan bahan berupa arang untuk kosmetik.

\section{- Potensi Sumberdaya Pariwisata}

Pariwisata bisa menjadi kegiatan yang bisa diandalkan untuk menopang ekonomi masyarakat. Kegiatan pariwisata di pesisir Demak bisa menjadi andalan untuk menarik wisatawan dan pada akhirnya dapat menambah penghasilan masyarakat. Pesisir Demak kaya akan berbagai atraksi wisata, mulai dari wisata 
alam, wisata budaya \& sejarah hingga wisata religi yang sudah tersohor hingga mancanegara.

Wisata alam yang ada di pesisir Demak antara lain adalah wisata hutan mangrove di desa Morosari Sayung dan wisata agrowisata belimbing dan jambu merah delima. Museum Masjid Agung Demak, sentra batik Demak, sentra kerajinan Kaligrafi, sentra kerajinan Rebana, serta perayaan Grebeg Besar Demak bisa menjadi destinasi wisata budaya dan sejarah di pesisir Demak. Selain itu, terdapat pula wisata religi yang sudah sangat terkenal sejak lama yakni wisata Masjid Agung Demak dan wisata makam Sunan Kalijogo. Sejarah yang ada di pesisir Demak sangat erat kaitannya dengan masa-masa kejayaan kerajaan Demak.

\section{c. Potensi Bencana \\ - Ancaman Erosi}

Ancaman erosi atau abrasi di pesisir Demak semakin hari semakin meluas karena tergerus ombak sehingga mengurangi garis pantai Demak, banyak wilayah pesisir Demak yang tenggelam akibat erosi tersebut. Proses terjadinya abrasi di wilayah pesisir Demak sangat dipengaruhi oleh faktor gelombang. Terjadinya perubahan iklim global berdampak pada peningkatan ancaman gelombang ekstrem dan erosi pada wilayah pesisir. Gelombang ekstrem disebabkan oleh sinkron tropis. Di Indonesia, kecepatan angin bisa mencapai 120 km/jam yang diiukuti dengan hujan lebat. Hal ini mengakibatkan terjadinya badai di wilayah pesisir dan gelombang tinggi air laut. Angin kencang dan tingginya gelombang kea arah daratan mendorong kubah air dan mengakibatkan banjir di daratan yang disebut banjir badai.

\section{- Ancaman Banjir Rob dan Land Subsidence}

Banjir pesisir di kawasan pesisir banyak terjadi di kota-kota pesisir. Banjir di kawasan pesisir merupakan akumulasi dari banjir genangan air laut, banjir kiriman, dan banjir luapan air sungai. Kawawan pesisir Demak merupakan salah satu kawasan yang rentan mengalami banjir pesisir. Perubahan iklim global berimplikasi pada kenaikan muka air laut. Kenaikan muka air laut akan mempengaruhi ketinggian gelombang, pada waktu-waktu tertentu akan 
mengakibatkan banjir. Aktivitas masyarakat yang sangat intensif terutama dalam menggunakan airtanah menjadi salah satu penyebab yang memperparah kondisi ini. Intensifnya penggunaan airtanah menyebabkan muka permukaan tanah menjadi turun. Kenaikan permukaan air laut ditambah dengan penurunan muka permukaan tanah menjadi kombinasi yang baik untuk terjadinya banjir genangan air laut. Kondisi di pesisir Demak sangat parah, banyak rumah, toko, pabrik yang berada di pesisir Demak telah tenggelam.

\section{- Sedimentasi}

Wilayah pesisir Demak memiliki karakteristik yang sangat dipengaruhi oleh geomorfologi lingkungan sekitar. Berada di pantai utara jawa, dengan karakteristik gelombang yang tenang dan selalu mendapat pasokan material dari pegunungan disekitar menyebabkan pesisir Demak rawan untuk terjadinya pengendapan. Berawal dari erosi di daerah perbukitan Ungaran \& Muria dan sekitarnya. Kemudian terbawa ke sungai dan kemudian mengendap di pesisir. Akibatnya banyak pesisir di wilayah ini yang terus tertimbun oleh material endapan. Sungai-sungai yang ada di pesisir Demak tak luput dari pengendapan. Sungai menjadi dangkal, airnya pun menjadi lebih keruh. Hal ini tentu akan mengganggu aktivitas masyarakat.

\section{d. Sustainable Coastal Area}

Zona kegiatan ekonomi dan industri direkomendasikan berada di kawasan daratan yang berada dekat dengan akses pelabuhan Tanjung Emas dan dekat dengan jalan pantura serta Tol utara Jawa (Gambar . Pemanfaatan ruang di kawasan sebenarnya sudah sangat massif oleh kebaradaan industry besar. Di kawasan ini terdapat industri dengan berbagai skala, mulai dari skala lokal, nasional hingga internasional. Kawasan industri di kawasan Demak menjadi salah satu sumber pendapatan daerah terbesar dan menyerap ribuan pekerja. Oleh karena itu, perlu adanya regulasi yang tepat. Regulasi yang tepat mempertingkan aspek ekonomi sebagai aspek utama dan tidak lupa memperhatikan aspek lingkungan sebagi aspek pendukung agar tercipta pemanfaatan ruang yang berkelajutan. 
Zona permukiman berada dekat dengan zona ekonomi dan industri. Pada zona ini banyak terdapat pemukiman masyarakat. Dengan topografi yang datar, terdapat fasilitas yang mendukung seperti air,sanitasi,jalan maka zona ini berkembang dengan pesat. Perkembangan permukiman sangat pesat salah satunya dipengaruhi oleh aktivitas ekonomi dan industry disekitarnya.

\section{Gambar 5: Peta Zonasi Sustainbele Coastal di Pesisir Demak}

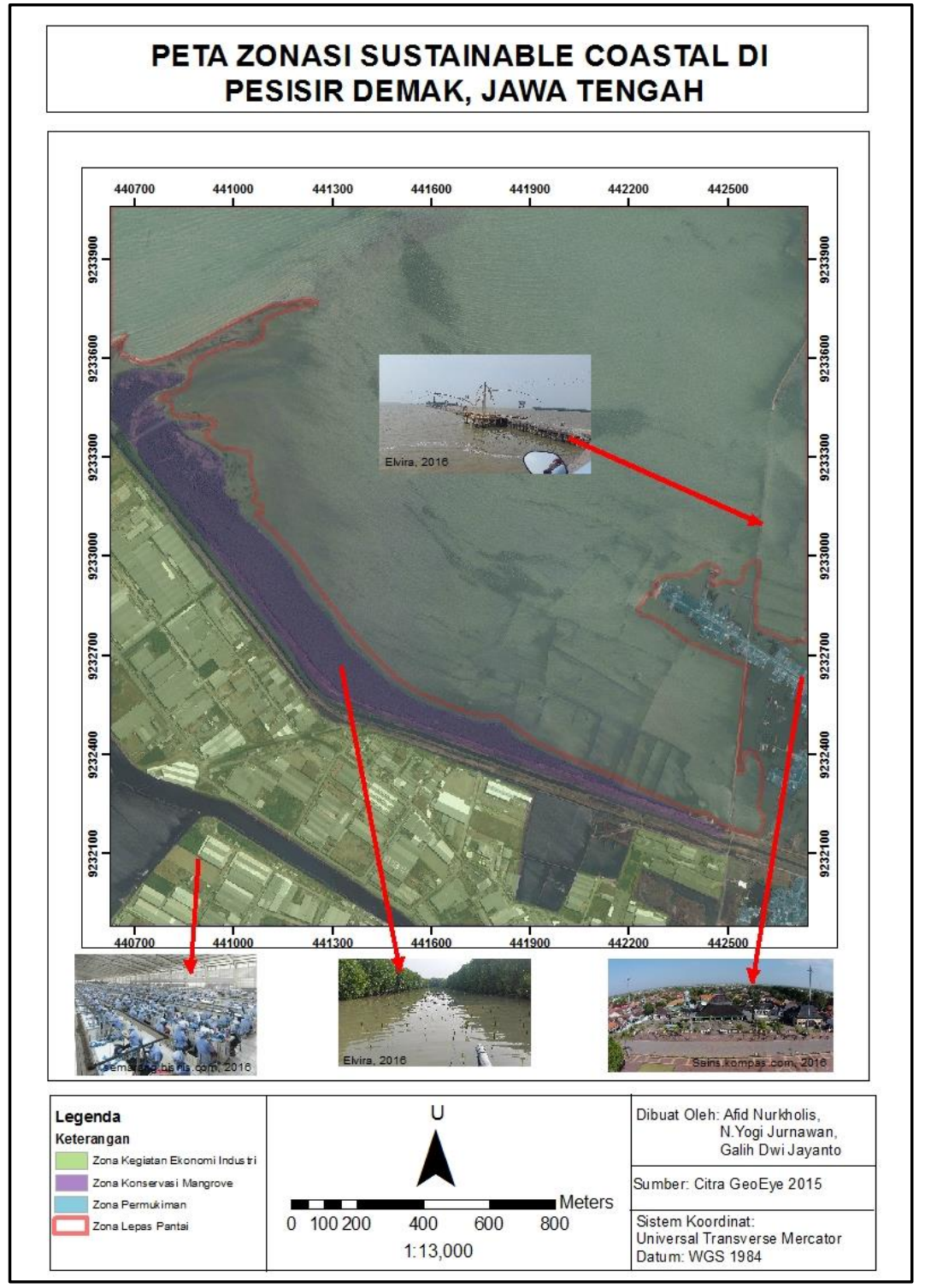

Sumber: Pengolahan Data,2016 
Zona konservasi berada di bentuklahan rataan pasang surut. Bentuklahan rataan pasang surut terbentukan karena aktivitas fluviomarin. Daerah ini berada dalam kondisi tergenang dan berlumpur. Letaknya yang berada diantara daratan dan laut berimplikasi kepada pemanfaatan dan peruntukan nya. Tidak ada perumahan, industry dan sarana fasilitas masyarakat. Pada zona ini hanya diperbolehkan untuk area konservasi. Oleh karena itu zona ini hanya diperbolehkan untuk area tanaman mangrove. Tanaman mangrove mampu menjadi tanaman konservasi. Hal tersebut karena tanaman mangrove mampu menjadi penanyangga ekosistem pesisir, menjadi tempat hidup berbagai biota dan menjadi tembok penahan ombak dan tsunami di kawasan pesisir. Keberadaan zona konservasi mangrove perlu terus ditingkatkan untuk menjaga keseimbangan ekosistem pesisir.

Kawasan pesisir Demak memiliki ancaman besar yaitu erosi pantai dan banjir pesisir (rob). Zona konservasi mangrove bisa menjadi solusi tepat guna untuk menanggulangi masalah tersebut. Selain menjadi penyangga ekosistem pesisir dan benteng alami dari gempuran ombak pesisir, kawasan konservasi mangrove bisa juga dijadikan sebagai kawasan pariwisata alami. Baru-baru ini sedang digencarkan pembangunan ekowisata mangrove di kawasan ini. Diharapkan dengan adanya aktivitas pariwisata di kawasan konservasi mangrove bisa menjadi sarana hiburan, edukasi, serta sarana ekonomi untuk mensejahterakan masyarakat pesisir. Tapi perlu dilakukan pengawasan oleh pemerintah untuk tetap menjaga zona konservasi agar tetap menjalankan fungsi utamanya yaitu sebagai zona konservasi wilayah pesisir. 


\section{BAB V: KESIMPULAN DAN REKOMENDASI}

\section{A. Kesimpulan}

1. Pesisir karst memiliki potensi utama berupa pariwisata yang menarik. Marine deposition coast memiliki potensi utama berupa pertanian, pariwisata, tambak, dan permukiman. Subaerial Deposition Coast memiliki potensi utama berupa tambak ikan, pelabuhan, dan konservasi hutan mangrove.

2. Pesisir karst memiliki potensi bencana berupa kekeringan, longsor tebing, dan erosi pantai. Marine deposition coast memiliki potensi bencana berupa tsunami, erosi pantai, pencemaran. Subaerial deposition coast memiliki potensi bencana berupa banjir rob, subsiden, sedimentasi, dan pencemaran.

3. Sustainable coastal area diciptkan dengan membuat zonasi berdasarkan aspek perwatakan lahan sesuai peruntukannya. Zonasi ini telah memperhatikan aspek ekonomi, kelestarian lingkungan, dan kelestarian budaya.

\section{B. Rekomendasi}

1. Analisis lahan dan air perlu dilakukan di setiap karakteristik pesisir Indonesia untuk mengevaluasi pembangunan dan melakukan perencanaan pebangunan di pesisir agar lestari.

2. Pemanfaatan sumberdaya alam pesisir seharusnya menyeseuiakan aspek perwatakannya agar tidak menimbulkan eksploitasi.

3. Partisipasi masyarakat lokal perlu ditingkatkan dalam pembangunan kawasan pesisir. 


\section{DAFTAR PUSTAKA}

Bentley MG, Pacey AA. 1992. Physiological and environmental control of reproduction in polychaetes. Oceanogr Mar Biol Ann Rev 30:443-481

Cahyadi, Ahmad.,Anggraini, Dini Feti. Tipologi, Dinamika, dan Potensi Bencana Di Pesisir Kawasan Karst Kabupaten Gunungkidul. Jurnal Geografi UMS Vol. 27, No. 2, Desember 2013: $151-162$.

Cicin-Sain, B. and R. W. Knecht. 1998. Integrated Coastal and Ocean ManagementConcepts and Practices. Washington D.C.: Island Press

Fabianto, M.D dan Pieter Th Berhitu. 2014. Konsep Pengelolaan Wilayah Pesisir SecaraTerpadu dan Berkelanjutan yang Berbasis Masyarakat. Jurnal TEKNOLOGI,Volume11 Nomor2, 2014; $2054-2058$

SHEPARD, F.P. 1937: Revised classification of marine shorelines. - In: Journ. Geol., 45,602- 624

Soegiharto, A. 1976. Sumber-sumber pencemaran. Seminar pencemaran laut. LON LIPI.ISOI. Jakarta.

Strahler, Arthur N. and Alan H. Strahler. 1984. Elements of Physical Geography, 3 rd Edition. John Wiley \& Sons: New York. 3 rd Edition

Triadmojo, Bambang. 1999. Teknik Pantai. Yogyakarta: Beta Offset

Verstappen, H. Th. 1983. Applied Geomorphology: Geomorphological Surveys for Environmental Development. Elsevier Science Publishing Company Inc: New York.

Dahuri, R. et al, 1996. Pengelolaan Sumberdaya Pesisir dan Lautan Secara Terpadu. PT. Pramadya Paramita, Jakarta.

Santosa, Langgeng. 2011. Bahan Ajar Kuliah: Tipologi Wilayah Pesisir. Yogyakarta: Fakultas Geografi UGM

Sunarto,.Marfai,M.A,.Setiawan,M.A. 2014. Geomorfologi dan Dinamika Pesisir Jepara. Yogyakarta: Gadjah Mada University Press 